\section{Forcing White Asparagus in Various Substrates under Cool and Warm Regimes}

\author{
Wallace G. Pill and Thomas A. Evans \\ Department of Plant and Soil Sciences, University of Delaware, Newark, \\ DE 19717-1303

\section{Stephen A. Garrison \\ Rutger's University Research and Education Center, Bridgton, NJ 08302}

Additional index words. Asparagus officinalis, blanched asparagus, spent mushroom compost

\begin{abstract}
One-year-old crowns of 'Jersey Giant' asparagus (Asparagus officinalis L.) were forced into spear production at $\mathbf{2 8 C}$ in darkness. Total spear fresh weight and number per square meter responded quadratically to the percentage of sand incorporated in Pro-Mix BX (PMX) peat-lite medium, with maximum yields at $25 \%$ to $75 \%$ (by volume) PMX. In a second study conducted at 22 and $28 \mathrm{C}$, total spear fresh weight and number per square meter for 96 days of harvest were similar when grown in weathered, spent mushroom compost (SMC) or 1 PMX : 1 sand (v/v), but were lower than those grown in PMX. The lower temperature caused heavier individual spears, while the higher temperature stimulated earlier spear production. During the first month of harvest at 22C, the total number and fresh weight of spears in SMC were $11 \%$ and $17 \%$ less, respectively, than in PMX. SMC may be a low-cost forcing substrate for white asparagus.
\end{abstract}

Asparagus grown in darkness does not synthesize chlorophyll, and spears remain white (Makus and Gonzales, 1991). Higher living standards and changing dietary habits have increased the demand for white asparagus, which commands a higher price than green asparagus (Poll et al., 1990). White asparagus is produced commonly in Asia and Europe. In the Netherlands, off-season (forced) asparagus produced between November and April sells for substantially more than in-season asparagus (Poll et al., 1990). Kramer (1988) estimated that the gross margin per labor hour for forced asparagus, mushroom [Agricus bisporus (Lange) Imbach], or witloof (Cicho-

Received for publication 24 Mar, 1993. Accepted for publication 29 May 1993. Published as miscellaneous paper 1284 of the Delaware Agricultural Experiment Station. Mention of trade names in this publication does not imply endorsement by the Delaware Agricultural Experiment Station of products named nor criticism of similar ones not mentioned. Contribution 311 of the Plant and Soil Sciences Dept. We gratefully acknowledge partial support for this research from the Alternative Crops and Marketing Research program, Delaware Dept. of Agriculture. The cost of publishing this paper was defrayed in part by the payment of page charges. Under postal regulations, this paper therefore must be hereby marked advertisement solely to indicate this fact. rium endivia L.) was about equal in the Netherlands. Fresh white asparagus is rare in major U.S. markets, and there is little demand for white asparagus in the eastern United States. White asparagus usually is two to three times more expensive than green asparagus (Makus and Gonzales, 1991 ).

White asparagus may be produced in the field under opaque plastic rowcovers (Makus and Gonzales, 1991) or under 1.5-m-high walk-in plastic tunnels in conjunction with black rowcovers (Vakis et al., 1975). White asparagus in the Netherlands is forced under ridged soil or black plastic in greenhouses once each year; production from individual crowns lasts 5 to 8 years (Poll et al., 1990). These authors described forcing asparagus in climatized rooms in multiple-layered trays with up to 10 forcing periods each year. Lamberts et al. (1988) described forcing white asparagus in 50 - to 60 -cm-deep $\times 40$ - to 50 $\mathrm{cm}$-wide containers of various lengths. The containers were kept outdoors during the growing season, then brought inside for spear forcing at 18 to $22 \mathrm{C}$ and $90 \%$ relative humidity for 4 to 6 weeks before being returned outdoors.

Forcing 2-year-old crowns in potting soil (undefined) produced more spears, greater average spear weight, and greater total fresh weight (39\%) per crown than hydroponic forcing (Poll et al., 1990). van Os and Simonse
(1988) reported that the average weight of spears forced in rockwool was as high as those forced in the field. Lamberts et al. (1988) suggested $75 \%$ peat and $25 \%$ inert coarse amendments such as calcined clay, perlite, or polystyrene beads as a forcing substrate for white asparagus. Spent mushroom compost (SMC)-compost collected from harvested mushroom beds-has been used as a soil amendment for vegetables (Wang et al., 1984) and as a growth medium component for containerized woody ornamental species (Chong et al., 1991). Some of the estimated 680,000 $\mathrm{m}^{3}$ of SMC produced annually in southern Pennsylvania (U.S. Dept. of Agriculture, 1992) could serve as a substrate for forcing asparagus spears.

The objective of Expt. 1 was to determine the feasibility of producing white asparagus in Pro-Mix BX (PMX) (Premier Brands, New Rochelle, N.Y.) peat-lite growth medium amended with various proportions of sand (no. 1 foundry; Whibco, Leesburg, N.J.). The objective of Expt. 2 was to compare PMX alone, 1 PMX : 1 sand (v/v), and SMC alone as substrates for white asparagus forced at two temperatures. One-year-old crowns of 'Jersey Giant' male hybrid asparagus were dug from the field in Mar. 1991 and stored at 4C until used in the experiments.

PMX and sand (Expt. 1). Insulated wooden boxes $(58.5 \mathrm{~cm}$ long $\times 37.5 \mathrm{~cm}$ wide $\times 35 \mathrm{~cm}$ deep) were placed on low-wattage propagation mats on the concrete floor of a cellar. The crowns (fresh weight $=251 \pm 54 \mathrm{~g}$ ) were soaked in $0.525 \% \mathrm{NaOCl}(10 \%$ bleach by volume) for $10 \mathrm{~min}$, rinsed, and allowed to dry. On 11 May 1991, the crowns were placed on $5 \mathrm{~cm}$ of substrate and covered with an additional $13 \mathrm{~cm}$ of the same substrate. Twenty-six crowns were planted in each box (one crown $/ 95 \mathrm{~cm}^{2}, 105$ crowns $/ \mathrm{m}^{2}$ ).

Substrates were PMX and sand $(99.3 \%$ silicon dioxide, $89 \%$ of weight between 1.7 and $0.9 \mathrm{~mm}$ in diameter) that were mixed in percentage volumetric proportions of 0:100, $25: 75,50: 50,75: 25$, or 100:0. The substrates were watered to container capacity once each week. The boxes were covered with removable 0.15 -mm-thick black plastic placed 30 $\mathrm{cm}$ above the substrate's surface to exclude light. Temperature sensors for the thermostatically controlled low-wattage propagation mats were placed at crown depth. Thermostats were adjusted to provide constant $28 \pm 3 \mathrm{C}$. Substrates were arranged in a randomized complete-block design with four replications.

Spears $\geq 15 \mathrm{~cm}$ tall were cut daily at the substrate's surface. The diameter $(5 \mathrm{~cm}$ from the base) and fresh weight of each spear were measured. These data were grouped into 7-day periods from the first harvest day (17 May) 
until the final harvest day (25 June). Data were subjected to analysis of variance (ANOVA) using SAS's PROC GLM program (SAS Institute, 1985).

The number of spears per square meter and the total spear fresh weight per square meter responded quadratically to the percentage of sand in the substrate during the first two harvests and as a cumulative total of all harvests (Table 1). Thus, $25 \%$ to $75 \%$ sand in PMX produced the highest white asparagus yields of all ratios. Yield responses maybe explained by differences in the substrates' physical and chemical properties. Poll and van Kruistum (1988) noted that adding dolomitic limestone at $50 \mathrm{~kg} \cdot \mathrm{m}^{-3}$ of potting mix increased the number of spears and total spear weight per crown, but not the average spear weight. Thus, adding limestone or other nutrients to the substrates could have increased yields further. Most of the nutrients required to support spear

Table 1. Yield for five harvests of 'Jersey Giant' asparagus forced in various volumetric percentages of sand and Pro-Mix BX (PMX) (Expt. 1).

\begin{tabular}{|c|c|c|c|c|c|c|}
\hline \multirow{2}{*}{$\begin{array}{l}\text { PMX : sand } \\
\text { (\% vol) }\end{array}$} & \multicolumn{5}{|c|}{ Harvest (days after forcing) } & \multirow[b]{2}{*}{ Total } \\
\hline & $6-13$ & $14-20$ & $21-28$ & $29-36$ & $37-44$ & \\
\hline \multicolumn{7}{|c|}{ No. spears $/ m^{2}$} \\
\hline $100: 0$ & 266 & 266 & 170 & 101 & 109 & 913 \\
\hline $75: 25$ & 335 & 315 & 182 & 113 & 97 & 1038 \\
\hline $50: 50$ & 347 & 355 & 206 & 113 & 113 & 1131 \\
\hline $25: 75$ & 307 & 323 & 198 & 109 & 109 & 1050 \\
\hline $0: 100$ & 246 & 303 & 170 & 93 & 113 & 888 \\
\hline Significance & $Q^{*}$ & $Q^{*}$ & NS & NS & NS & $\mathbf{Q}^{*}$ \\
\hline \multicolumn{7}{|c|}{ Spear fresh $w t\left(g \cdot m^{-2}\right)$} \\
\hline $100: 0$ & 509 & 416 & 266 & 174 & 121 & 1470 \\
\hline $75: 25$ & 682 & 541 & 291 & 178 & 170 & 1845 \\
\hline $50: 50$ & 638 & 553 & 283 & 174 & 141 & 1765 \\
\hline $25: 75$ & 614 & 517 & 275 & 170 & 145 & 1712 \\
\hline $0: 100$ & 489 & 509 & 250 & 170 & 113 & 1498 \\
\hline Significance & $Q^{*}$ & $Q^{*}$ & NS & NS & NS & $\mathrm{Q}^{*}$ \\
\hline
\end{tabular}

ws, ${ }^{*}$ Nonsignificant or significant at $P \leq 0.5 ; \mathrm{Q}=$ quadratic. growth are available from root reserves, although some N, Ca, and S can be absorbed (Robb, 1984).

The total yields averaged $\approx 10$ spears/crown and spear fresh weight was $16 \mathrm{~g} /$ crown. Poll and van Kruistum (1988) reported $\approx 9$ spears/ crown (22 cm long) and a spear fresh weight of $79 \mathrm{~g} /$ crown for 'Jersey Giant' forced for 1 month at $25 \mathrm{C}$. Although the number of spears per crown was similar, total spear fresh weight per crown was much lower in our study. Our lower total yield per crown may have been due to the lower initial crown fresh weight and, thus, lower carbohydrate reserves of 1-year-old (251 g) compared with 2-year-old (450 g) crowns in the study by Poll and van Kruistum (1988). Poll et al. (1990) reported 75\% higher yield from 3-year-old crowns than from 2 -year-old crowns. Spear count and fresh weight within a substrate declined with successive harvests (Table 1), as reported by Poll et al. (1990). Spear diameters in our study also decreased from $3.6 \mathrm{~mm}$ at the first harvest to $1.6 \mathrm{~mm}$ by the last harvest (detailed data not shown). As harvesting progresses, apical dominance becomes stronger, spear production diminishes (Robb, 1984), and less reserve carbohydrate is available for spear growth. In our study, substrate did not affect spear fresh weight or diameter at arty harvest (data not shown).

SMC and temperature (Expt. 2). Sixteen 1-year-old 'Jersey Giant' crowns per box (fresh weight $=204 \pm 93 \mathrm{~g}$ ) were planted on $17 \mathrm{Apr}$. 1991. The $2 \times 3$ factorial experiment consisted of two constant-temperature treatments at crown depth $(\mathrm{cool}=22 \mathrm{C}$, warm $=28 \mathrm{C})$ and three substrate treatments [PMX alone, 1 PMX : 1 sand (v/v), and SMC alone]. SMC was 27 horse manure : 27 wheat straw : 27 orchard grass : 4 corn cobs : 4 cotton seed meal : 4 chicken manure : 7 sphagnum moss (percent volume). Dolomitic limestone $\left(1.2 \mathrm{~kg} \cdot \mathrm{m}^{-3}\right)$ had been added to the SMC before mushroom culture, after which the SMC had weathered naturally for 18 months. Treatments were arranged in a randomized complete-block design with four replications. All cultural details were the same as described for Expt. 1. The number and fresh weight of spears harvested daily from each box were recorded and the data were subjected to ANOVA as in Expt. 1.

During the first 18 days of forcing, the warm regime produced more spears; however, the cool regime produced more spears per square meter between 71 and 96 days (Table $2)$. Temperature did not influence the total number of spears produced over the 96-day forcing period. Thus, the higher temperature stimulated earlier bud growth. Despite the slowed emergence between days 45 and 57, spear emergence was fairly constant, with an average of 199,172 , and $159 / \mathrm{m}^{2}$ per week in

Table 2. Yield for seven harvests of 'Jersey Giant' asparagus forced in various substrates (S) under two temperature (T) regimes (Expt. 2).

\begin{tabular}{|c|c|c|c|c|c|c|c|c|c|}
\hline \multirow[b]{2}{*}{$\underline{\text { Regime }}^{\mathrm{z}}$} & \multirow[b]{2}{*}{ Substrate $^{y}$} & \multicolumn{7}{|c|}{ Harvest (days after forcing) } & \multirow[b]{2}{*}{ Total } \\
\hline & & 6-18 & 19-31 & $32-44$ & $45-57$ & $58-70$ & $71-83$ & $84-96$ & \\
\hline \multicolumn{10}{|c|}{ No. spears $/ m^{2}$} \\
\hline \multirow[t]{3}{*}{ Cool } & PMX & 218 & 226 & 204 & 95 & 154 & 257 & 244 & 1399 \\
\hline & PMX : sand & 193 & 197 & 206 & 89 & 144 & 195 & 179 & 1203 \\
\hline & SMC & 195 & 201 & 207 & 80 & 138 & 167 & 167 & 1155 \\
\hline \multirow[t]{3}{*}{ Warm } & PMX & 324 & 228 & 203 & 95 & 151 & 173 & 158 & 1332 \\
\hline & PMX : sand & 304 & 218 & 160 & 76 & 128 & 127 & 136 & 1149 \\
\hline & SMC & 284 & 195 & 164 & 84 & 138 & 95 & 71 & 1031 \\
\hline $\mathrm{LSD}_{0.05}$ (two-way) & & 57 & \multirow{2}{*}{\multicolumn{5}{|c|}{ Significance }} & 96 & 212 \\
\hline $\begin{array}{l}\text { Significance } \\
\mathrm{T}\end{array}$ & & $* * *$ & & & & & & ** & NS \\
\hline$S$ & & Ns & ns & NS & NS & NS & $*$ & NS & ** \\
\hline $\mathrm{S} \times \mathrm{T}$ & & NS & NS & NS & NS & NS & NS & NS & NS \\
\hline \multicolumn{10}{|c|}{ Spear fresh $w t\left(g \cdot m^{-2}\right)$} \\
\hline \multirow[t]{3}{*}{ Cool. } & PMX & 632 & 626 & 537 & 489 & 241 & 308 & 248 & 3081 \\
\hline & PMX : sand & 572 & 503 & 515 & 391 & 218 & 260 & 140 & 2600 \\
\hline & SMC & 558 & 489 & 421 & 325 & 161 & 171 & 129 & 2254 \\
\hline \multirow[t]{3}{*}{ Warm } & PMX & 857 & 458 & 300 & 303 & 165 & 169 & 122 & 2374 \\
\hline & PMX : sand & 696 & 393 & 237 & 233 & 128 & 128 & 84 & 1899 \\
\hline & SMC & 637 & 294 & 209 & 199 & 113 & 68 & 40 & 1559 \\
\hline $\mathrm{LSD}_{0.05}$ (two-way) & & 210 & 147 & 101 & 116 & 66 . & 83 & 80 & 637 \\
\hline \multicolumn{10}{|l|}{ Significance } \\
\hline $\mathrm{T}$ & & * & $* * *$ & $* * *$ & $* * *$ & $* * *$ & $* * *$ & $* * *$ & $* * *$ \\
\hline $\mathbf{S}$ & & NS & * & $*$ & $* *$ & $*$ & $* *$ & $* *$ & $* *$ \\
\hline $\mathrm{T} \times \mathrm{S}$ & & NS & NS & NS & NS & NS & NS & NS & NS \\
\hline
\end{tabular}

${ }^{z}$ Cool $=$ constant $22 \mathrm{C}$, warm $=$ constant $28 \mathrm{C}$.

yPMX = Pro-Mix BX, PMX : sand $=$ each $50 \%$ by volume, $\mathrm{SMC}=$ spent mushroom compost.

${ }^{\mathrm{N}, *,+*,+*+*}$ Nonsignificant or significant at $P \leq 0.001,0.01$, or 0.05 , respectively. 
PMX alone, PMX : sand, and SMC alone, respectively.

The warm regime produced a higher spear fresh weight per square meter between 6 and 18 days of harvesting; but, thereafter (19 to 96 days) the cool regime did (Table 2). The cool regime produced a $36 \%$ higher total spear fresh weight per square meter than the warm regime for all harvests. Since temperature did not affect total spear count for all harvests, the higher total spear fresh weight per square meter with the cool regime can be attributed to heavier individual spears $(2.1 \mathrm{~g})$ than with the warm regime $(1.6 \mathrm{~g})$. These results agree with those of Poll and van Kruistum (1990). Of the fructo-oligo-saccharide storage carbohydrates, one-third is lost to spears, while the rest is used in respiration and in the growth of new roots and buds (Robb, 1984). The higher temperature in our study may have raised the respiration rate and lessened the reserves available to support long-term spear production. By the end of the forcing period, crown fresh weights decreased $57 \%$ (to $88 \mathrm{~g}$ ) in the warm regime but only $25 \%$ (to $154 \mathrm{~g}$ ) in the cool regime.

Over the 96-day forcing period, PMX produced more spears per square meter than PMX : sand or SMC (Table 2). PMX produced higher spear fresh weights than SMC for most harvests (19 to 96 days); however, spear fresh weights in SMC or PMX: sand were similar. Total spear fresh weight in either 1 PMX : 1 sand or SMC was $18 \%$ or $30 \%$ less, respectively, than in PMX. Substrate primarily influenced the number of spears produced (Table 2) rather than individual spear fresh weight (data not shown).

As harvesting progressed, spear fresh weight per square meter decreased (Table 2). Within the fist month of harvest, the cool regime yielded $33 \%$ of its total number of spears and $43 \%$ of its total spear fresh weight; the warm regime yielded $44 \%$ and $57 \%$, respectively. Thus, the warm regime, relative to the cool regime, hastened bud growth and increased early yield, but decreased individual spear weight.

Higher initial substrate electrical conductivity, to which $\mathrm{K}$ and $\mathrm{N}$ contributed predominantly, in SMC than in PMX (Table 3) may have caused the lower total number of spears and lower spear fresh weight per square meter in SMC. Since SMC did not produce fewer spears or a lower fresh weight than PMX, the higher electrical conductivity of the compost could not be the sole cause of the lower yield in SMC. Saturated extract electrical conductivity values (in deciSiemens per meter) by the end of the cropping period were $0.27 \pm 0.07$ (PMX), $0.16 \pm 0.05$ (PMX : sand), and $2.23 \pm$ 0.36 (SMC).

Asparagus is classified as tolerant to salinity (Maas and Hoffman, 1977). Francois (1987)

Table 3. Substrate chemical properties before planting asparagus crowns in Expt. 2.

\begin{tabular}{|c|c|c|c|}
\hline \multirow{3}{*}{$\begin{array}{l}\text { Chemical } \\
\text { property }^{y}\end{array}$} & \multicolumn{3}{|c|}{ Mean $\pm \operatorname{sD}(n=4)$} \\
\hline & \multicolumn{3}{|c|}{ Substrate $^{2}$} \\
\hline & SMC & PMX : sand & PMX \\
\hline $\mathrm{pH}$ & $6.63 \pm 0.05$ & $5.94 \pm 0.08$ & $5.75 \pm 0.06$ \\
\hline Electrical conductivity $\left(\mathrm{dS} \cdot \mathrm{m}^{-1}\right)$ & $18.45 \pm 1.56$ & $1.16 \pm 0.11$ & $1.35 \pm 0.15$ \\
\hline Total N (percent dry weight) & $1.18 \pm 0.17$ & $0.08 \pm 0.01$ & $0.19 \pm 0.01$ \\
\hline \multicolumn{4}{|c|}{ Available elemental concentration (mg.liter ${ }^{1}$ ) } \\
\hline $\mathrm{P}$ & $16.2 \pm 1.7$ & $12.9 \pm 1.3$ & $31.4 \pm 2.6$ \\
\hline $\mathrm{K}$ & $486 \pm 52$ & $47 \pm 4$ & $95 \pm 11$ \\
\hline $\mathrm{Mg}$ & $49 \pm 5$ & $18 \pm 4$ & $40 \pm 9$ \\
\hline $\mathrm{Ca}$ & $120 \pm 12$ & $63 \pm 9$ & $117 \pm 16$ \\
\hline Mn & $0.09 \pm 0.02$ & $0.08 \pm 0.01$ & $0.12 \pm 0.04$ \\
\hline Zn & $0.07 \pm 0.01$ & $0.22 \pm 0.06$ & $0.51 \pm 0.11$ \\
\hline $\mathrm{Fe}$ & $2.4 \pm 0.5$ & $5.7 \pm 0.8$ & $9.8 \pm 1.3$ \\
\hline
\end{tabular}

${ }^{2} \mathrm{SMC}=$ spent mushroom compos; PMX $=$ Pro-Mix BX.

'All chemical properties (except total $\mathrm{N}$ concentration) were determined on a saturated water extract equilibrated for $1.5 \mathrm{~h}$ before filtration under suction for $0.5 \mathrm{~h}$.

noted that the maximum (threshold) soil salinity without a decline in spear yield in 'UC 157' asparagus was $4.1 \mathrm{dS} \cdot \mathrm{m}^{-1}$ (saturated extract). A salinity of $18 \mathrm{dS} \cdot \mathrm{m}^{-1}$ in solutions containing equal weights of $\mathrm{NaCl}$ and $\mathrm{CaCl}_{2}$ decreased spear yields by $25 \%$. A similar salinity level of $18.4 \mathrm{dS} \cdot \mathrm{m}^{-1}$ (Table 3) was found in SMC at the beginning of the forcing period.

Wang et rd. (1984) found large increases in leaf $\mathrm{K}$ concentration of four vegetable species when increasing amounts of SMC were added to soil. Leaf $\mathrm{Mg}$ concentration decreased as leaf $\mathrm{K}$ concentration increased. Thus, the high $\mathrm{K}$ concentration of SMC (Table 3) may have antagonized $\mathrm{Mg}$ (and possibly $\mathrm{Ca}$ ) uptake, resulting in deficiency-mediated low spear yield. Lemaire et al. (1985) reported an increasing soluble $\mathrm{K}$ concentration from SMC as it continued to weather.

Lemaire et al. (1985) noted a $42 \%$ volume loss of SMC that had received periodic irrigation for 6 months. During this period, available water content increased as air content decreased, a result indicating increased microporosity. These researchers noted, however, that the initial low available water content of SMC could be increased by adding $25 \%$ to $50 \%$ (by volume) peat. Imperceptible shrinkage of SMC during the 3-month forcing period of our study leads us to conclude that the compost's physical properties changed little.

The results of this research indicate that white asparagus can be forced successfully in SMC alone, because of its low cost relative to PMX. Forcing at $22 \mathrm{C}$, compared with $28 \mathrm{C}$, for only 1 month resulted in higher average spear fresh weight and diameter. Forcing at $28 \mathrm{C}$ for 1 to 2 weeks to initiate spear development followed by $22 \mathrm{C}$ may be beneficial.

\section{Literature Cited}

Chong, C., R.A. Cline, D.L. Rinker, and O.B. Allen. 1991. Growth and mineral nutrient status of containerized woody species in media amended with spent mushroom compost. J. Amer. Soc. Hort. Sci. 116:242-247.

Francois, L.E. 1987. Salinity effects on asparagus yield and vegetative growth. J. Amer. Soc. Hort. Sci. 112:432-436.

Kramer, C.F.G. 1988. Economic aspects of asparagus forcing in climatised rooms. Asparagus Res. Nwsl. 1:30-34.

Lamberts, D., E. Schrevens, and L. Lettani. 1988. Research in Belgium on white asparagus production in forcing cells. Asparagus Res. Nwsl. 1:28-29.

Lemaire, F., A. Dartigues, and L.M. Rivière. 1985. Properties of substrate made with spent mushroom compost. Acta Hort. 172: 13-29.

Maas, E.V. and G.J. Hoffman. 1977. Crop salt tolerance-Current assessment. J. Irr. Drainage Div., Amer. Soc. Civil Eng. 103(IR2):115-134.

Makus, D.J. and A.R. Gonzales. 1991. Production and quality of white asparagus grown under opaque rowcovers. HortScience 26:374-377.

Poll, J.T.K., C.F.G. Kramer, and G. van Kruistum. 1990. Forcing of asparagus in climatised rooms during the off-season. Acta Hort. 271:1 63-171.

Poll, J.T.K. and G. van Kruistum. 1988. First experiences in forcing green in comparison to white asparagus. Asparagus Res. Nwsl. 1:35-40.

Poll, J.T.K. and G. van Kruistum. 1990. Effect of temperature on yield and quality of forced asparagus. Acta Hort. 267:151-152.

Robb, A.R. 1984. Physiology of asparagus (Asparagus officinalis) as related to the production of the crop. N.Z.J. Expt. Agr. 12:251-260.

SAS Institute. 1985. SAS user's guide: Statistics. SAS Institute, Cary, N.C.

U.S. Dept. of Agriculture. 1992. Mushrooms. Natl. Agr. Stat. Serv., Wash., D.C. Vg 2-1-2.

Vakis, N.J., C. Gregoriou, and A. Ioannou. 1975. Trials on asparagus blanching and earliness. Agr. Res. Inst., Ministry Agr., Nicosia, Cyprus. Tech. Paper 12.

van Os, E.A. and L. Simonse. 1988. Forcing asparagus in water. Acta Hort. 221:335-346.

Wang, S.H., V.L. Lohr, and D.L. Coffey. 1984. Spent mushroom compost as a soil amendment for vegetables. J. Amer. Soc. Hort. Sci. 109:698702 . 